\title{
縔合論文 マイクロエマルション系の構造の 温度・压力依存性
}

\author{
瀬戸秀紀 ${ }^{a}$. 長尾道弘 ${ }^{b}$. 川端庸平 ${ }^{c}$ \\ a 京都大学大学院理学研究科（T606-8502 京都市左京区北白川追分町） \\ b 東京大学物性研究所附属中性子科学研究施設 (T319-1106 那珂郡東海村白方 106-1) \\ c 東京都立大学大学院理学研究科（干192-0397 八王子市南大沢 1-1）
}

両親媒性物質を水や油と混合することによって得られるミセルやマイクロエマルションの系は, 「ソフトマター物理 学」の対象の一つとして注目を集めている。我々はこの観点から，イオン性界面活性剂 AOT と水, デカンからなる系 について, 中性子小角散乱, X線小角散乱, 中性子スピンエコーを用いてセミミクロ構造の形成要因, 特に温度変化 と圧力変化の違いについて，モデルと対応させながら詳細に検討した。これにより，温度効果は親水基側に顕著であ るのに対して圧力効果は疎水基間の相互作用を変化させること, それが膜の曲率剛性率の変化に関係していること, その一方で温度上昇と压力上昇により同様のセミミクロ構造の変化が見られることを示した。

（連絡者：瀬戸秀紀）Vol.3, No.10, 511 (2003)

\section{縔合論文 マイクロエマルションの現象論}

好村滋行

東京都立大学大学院理学研究科化学専攻（干192-0397 東京都八王子市南大沢 1-1）

近年のソフトマター研究について，凝縮系物理学の観点から概観する。ソフトマターに共通の性質は，メソスコ ピックな長さのスケールの存在であり，それが系の特徵を決定する上で重要な役割を果している。ソフトマターの一 例として, 水, 油, 界面活性剤から成るマイクロエマルションを考察する。マイクロエマルションは熱力学的に安定 で，様々な相挙動を示すことが知られている。このような系を理解するために，格子スピンモデル，ギンズブルグーラ ンダウ理論，膜の曲率弾性理論のような現象論的理論が重要であることを強調する。これらのすべての理論は，マイ クロエマルションの基礎的性質を理解する上で役立っている。最後に，高分子マイクロエマルションに関する最近の 実験的および理論的進展について簡単にレビューする。 


\title{
マイクロエマルション系の構造の温度・压力依存性 Temperature and Pressure Dependences of a Microemulsion System
}

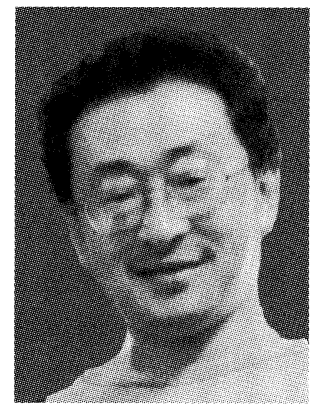

瀬戸秀紀

京都大学大学院理学研究科

于606-8502

京都市左京区北白川追分町

Hideki SETO

Graduate School of Science, Kyoto University

Kitashirakawa Oiwakecho, Kyoto 606-8502, JAPAN

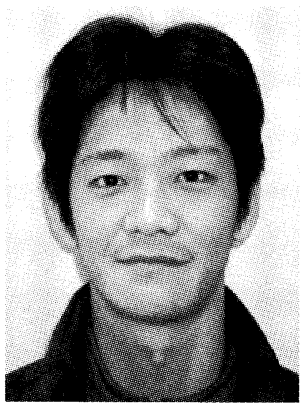

長尾道弘

東京大学物性研究所付属 中性子科学研究施設

T319-1106

那珂郡東海村白方 106-1

Michihiro NAGAO Institute for Solid State Physics,

The University of Tokyo 106-1 Shirakata, Tokai 319-1106, JAPAN

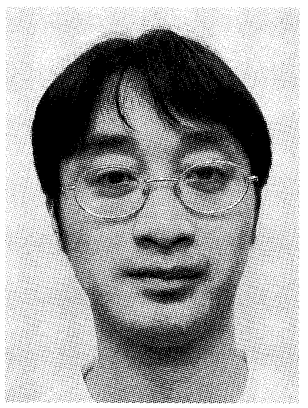

$$
\begin{gathered}
\text { 川端庸平 } \\
\text { 東京都立大学大学院理学研究科 } \\
\text { ₹192-0397 } \\
\text { 八王子市南大沢 1-1 }
\end{gathered}
$$

Youhei KAWABATA Department of Chemistry, Faculty of Science, Tokyo Metropolitan University Minamiosawa, Hachioji 192-0397, JAPAN

\begin{abstract}
In these decades, amphiphilic systems are widely interested as typical systems to investigate self-organizations in soft-matter physics. A mixture of AOT, water and decane is the most popular systems in such the studies. The temperature- and pressure-induced phase transitions have been invesitigated by means of small-angle neutron and X-ray scattering and neutron spin echo. The results showed that the microscopic origins of temperature- and pressure-induced phase transitions were different, however, the effects of temperature and pressure on the semi-microscopic scale structure seemed to be the same.
\end{abstract}

Key words: Microemulsion, Soft-matter Physics, Small-angle Scattering, Neutron Spinecho, Pressure-induced Phase Transition

1 はじめに

一つの分子中に水になじむ部分（親水基）と油になじ む部分（疎水基）を持つ両親媒性分子は，太古より人類 の生活に密着している。その利用法は石喃として, 食品 としてなど多様であり, 両親媒性分子なしでの生活は成 り立たない，と言って過言ではない。また細胞膜などの 生体中の膜は両親媒性分子の一種であるリン脂質と蛋白 質から構成されており，生命現象はそもそも両親媒性分 子があって初めて成り立つと言ってよい。従って少なく とも化学, 生物学, また工業的応用の面から見れば, こ

連絡者：瀬戸 秀紀

E-mail : st@scphys.kyoto-u.ac.jp
れら両親媒性分子とそれを含む物質系は古くからの研究 対象であり, 非常に多くの様々な研究が行われてきた し，また現在でも進行している。

しかし，物理学者にとってはこれらの系はいまだにエ キゾチックな香りを放っている。「物性物理」が「固体 物理」には限らないこと, それ以外の物質系（固体では ない，と言うことから「ソフトマター」と総称される） も物理学の対象になりうる事が分かってきたのは, 物理 学と他の学問の長い歴史からすればごく最近の事であ る ${ }^{1)}$ 。ワンンとクリックが DNA の二重らせん構造を 発見したところから始まったいわゆる「生物物理学」の 歴史はちょうど半世紀を迎えたところだが，「ソフトマ ター物理」と言う学問分野が意識されたてからは，拈そ 
らくその半分程度の期間しかたっていない。昨年, 物理 学会の年会で「ソフトマター物理の挑戦」と言うタイト ルでこの両親媒性分子系やコロイド，高分子，生体物質 等に関する物理学の最前線を紹介するシンポジウムを 行ったが，その中で最も印象的だった質問の一つが 「『ソフトマター物理』は,『物理学』なんですか?」と 言うものであった事に, 物性物理学の現状が象徴されて いると言えるのではなかろうが

では, これら両親媒性分子系, 特に界面活性剂と水, 油からなるマイクロエマルション系を, 物理学者が理解 しょうとする上でのキーワードは何か。それは，「セミ ミクロ構造」(「ナノ構造」や「メゾスコピック構造」と 言う言葉も用いる）であり，あるいは「自己組織化」で ある。これまで物性物理学が主に対象としてきた固体な どの系は数 $\mathrm{A} ら 10 \AA$ 程度を単位としていて, その構 造形成要因や物性発現の機構は電子論を基礎に詳しく調 ベられている。一方で $\mu \mathrm{m}$ 程度以上を特徴的長さとする マクロ系は熱統計力学の対象であり, こちらも物理学と してほぼ理解されていると言って良い（少なくとも平衡 論的には）が，その間のスケール（数十〜数百 ^）は極 端に言えば「物理学的な空白領域」であり，統一的に理 解されているとは言い難い。従って比較的単純な物質系 であるにも関わらず条件に応じて様々なセミミクロ構造 を取るミセルやマイクロエマルションを研究することに より，七ミミクロ系の構造形成（自己組織化）の一般論 を導くことができるのではないか, と期待されるのであ る。

もう一つ，これらの系を対象にする上で重要な視点は 「動的振舞い」である。上に述べたように固体でないも のを対象とする物理学全般をソフトマター物理と言う が，実際にそれらの物質系は固体に比べて「ソフト」で ある。これは言葉を変えれば外力に対する応答性が良 い，と言うことであり，熱的な摇らぎの影響を受けやす いと言うことでもある。生命現象を理解する上では静的 な安定状態だけではなくエネルギーの流入を伴う動的な 時間・空間構造が重要である，と言う考えは一般的に定 着して来ていると思われるが，ソフトマターはそれを理 解する上でのモデル系としても捉えることができる。ゆ えに両親媒性分子を含む系を物理学の组上に乗せるに は，構造形成要因を動的な振舞い（ダイナミクス）をも 含めて理解することが非常に重要なのである。

本稿では以上のような観点から, 水, 油, 界面活性剂 からなるマイクロエマルション系のセミミクロ構造につ いて, 温度変化と圧力変化を比較しながら静的な構造と 動的な構造の両面から理解しようとした研究について紹 介する。

\section{2 マイクロエマルションのセミミクロ構造}

マイクロエマルションとは，水，油，界面活性剤を用 いて一様に混合したいわゆる「エマルション」のうち, 特徵的な長さ，例えば水や油が連続している領域の空間 スケールが数百 丸を越えないものを指す。可視光の波長 は 4000〜 6000 A程度だから，光を散乱せず透明な液体 に見えるが，もっと小さなスケールで見ると必ずしも一 様ではなく，水や油の領域が分布していて界面活性剤の 膜を挟んである程度規則的に並んでいる。Fig. 1 は水， 油，界面活性剂を混合して得られる典型的な相図を模式 的に描いたものだが，マクロに相分離する領域（斜線が 走っている部分が 2 相領域，グレーになっている部分が 3 相領域）を除くと一様に混合していて，それぞれが違 う構造（セミミクロ構造）になっている。そしてこの相 罒は温度や压力などの外的な条件によって変化する。す なわち温度や圧力を変えることにより，これらセミミク 口構造の間の相転移を見ることができる。相転移現象を 理解することにより構造形成要因を探るのは物性物理学 の常道だが，マイクロエマルションについても同様のア プローチが通用するはずである。

水と油と界面活性剤を混合したときに得られる安定構 造は，何によって決まるのか。それは，系全体の界面工 ネルギーを小さくするように，と言うのが大原則であ る。水は水, 油は油で寄り集まってお互いの接触面積を なるべく小さくするようにした方が系全体のエネルギー を小さくできるので，界面活性剤なしに2つを混合しよ うとしても両者は上と下とに分離するしかない。ところ が界面活性剂は，この水と油の界面に吸着することに よって，界面エネルギーを劇的に下げることができる。 界面の広さは界面活性剂の量で決まり，水や油の領域の 大きさもそれぞれの量で決まるから, 水, 油, 界面活性 剂を混合する比を決めれば取りやすい構造はほぼ自動的 に決まると考えて良い3)。

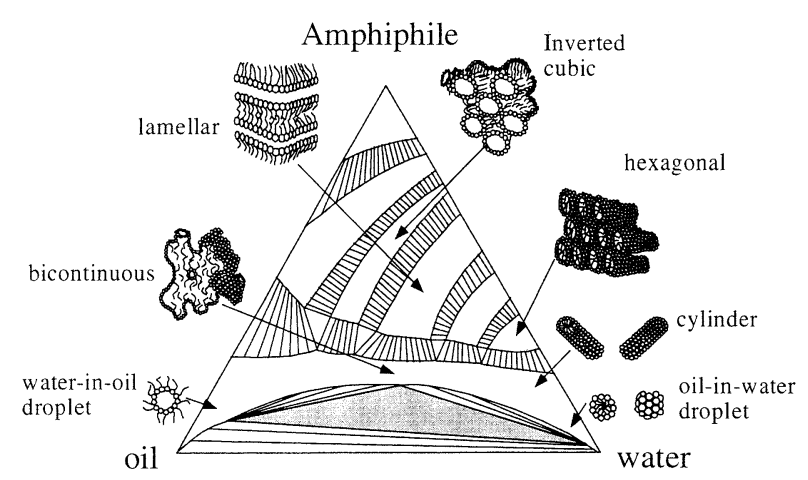

Fig. 1 水, 油, 界面活性剂 3 元系の典型的な相図。 
しかしながら，現実にはこのセミミクロ構造は組成だ けでは決まらないのである。それは温度や圧力などの条 件を変えることによって構造が変化することから分か る。これを理解する上でキーとなるコンセプトを与えた のは, Helfrich である ${ }^{4)}$ 。彼は界面活性剂膜を弾性膜と して扱い，膜の自然な曲がり方 (自発曲率 $R_{\mathrm{s}}{ }^{-1}$ とする) と膜の曲げやすさ（曲げ剛性率 $\kappa$ と, saddle-splay 剛性 率 反)を用いて，次の形の界面エネルギーを定義した。

$$
F=\int\left[\frac{\kappa}{2}\left(\frac{1}{R_{1}}+\frac{1}{R_{2}}-\frac{2}{R_{\mathrm{s}}}\right)^{2}+\bar{\kappa} \frac{1}{R_{1} R_{2}}\right] d S
$$

ここで $R_{1}^{-1}, R_{2}{ }^{-1}$ は界面の各点における主曲率である。 この式の第一項は界面を自発曲率から外れるように曲げ た場合のエネルギー損失を表しており，第二項は鞍点を 作ったときのエネルギー損失を表す。すなわちこの式全 体で界面活性剂膜を変形させたときのエネルギー損失を 表して抢り，これを「曲率エネルギー」と呼ぶ。水や油 への溶解性が低い界面活性剂の場合，分子が界面に飽和 している事と分子あたりの面積を最小化することによ り，通常の界面エネルギーの項を無視できる。従って， 膜の平衡の形や摇らぎの大きさ，相転移などの系の定性 的な振舞いは，この式が含む 3 つのパラメー夕 $R_{\mathrm{s}}^{-1}, \kappa, \kappa$ で特徴づけることができる。すなわちマイクロエマル ションの構造形成要因を明らかにするためには，これら のパラメー夕を実験的に決めること，そしてその決定要 因について議論することが非常に重要なのである。

\section{AOT と水とデカンの系}

以上のような観点からマイクロエマルションの構造形 成要因を調べた例として, 我々の研究グループによるイ オン性界面活性剤 AOT (dioctyl sulfosuccinate sodium salt）と水，そして油としてデカンに関する研究を紹介 する。この系はコサーファクタントや塩などを添加する ことなく広い組成範囲で一様になることから，これまで 多くの研究がなされて来た系である。Fig. 2 は室温常圧 における相図である。この三元系の構造については,こ れまで次のようなことが分かっていた

1） AOT 分子の踈水基は 2 本で親水基へッドに比べ て体積が大きいため，自発曲率が正である。すな わち界面活性剂が凝集すると，水を内側にする方 向に曲がりやすい。そのため広い組成範囲で water-in-oil droplet 構造を形成する。

2) droplet サイズはAOTと水の体積比で決まる。 これは水の体積が dropletの体積と, AOT の体 積が droplet の表面積と関係しているからである。 Fig. 2 の斜めの矢印は dropletサイズが一定のラ

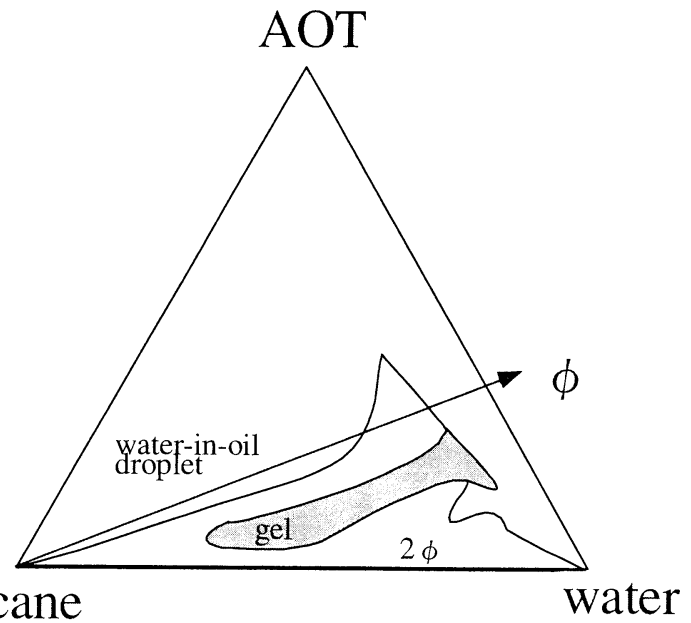

Fig. 2 AOT, デカン, 水の三元系の室温常圧に打ける相図。 矢印上では水と AOT の組成比が一定で, dropletの 半径が等しく濃度のみが変化する擬一元系描像が成 り立っている。

インで，全体に対する AOT と水の体積分率の和 を $\phi$ とする $\left(\phi=\left(\phi_{\mathrm{AOT}}+\phi_{\text {water }}\right) /\left(\phi_{\mathrm{AOT}}+\phi_{\text {water }}+\phi_{\text {decane }}\right)\right)$ と， $\phi$ は droplet 濃度を表すと考える事ができる。 すなわちこのライン上では, 「擬一元流体系」と 考えることができる。

3） Fig. 3 に, droplet 濃度と温度 $T$ についての相図 を示す。 $\phi<0.4$ の「希薄 droplet」では温度上昇 により相分離し， $\phi=0.1$ 付近の組成で droplet 濃 度摇らぎに起因する臨界現象を示す。この現象の 臨界普遍性は単純流体系と同じ 3 次元 Ising であ る事が分かって扔り，流体中に同一サイズの droplet が分散していると言う「擬一元流体系」 の描像に一致する。

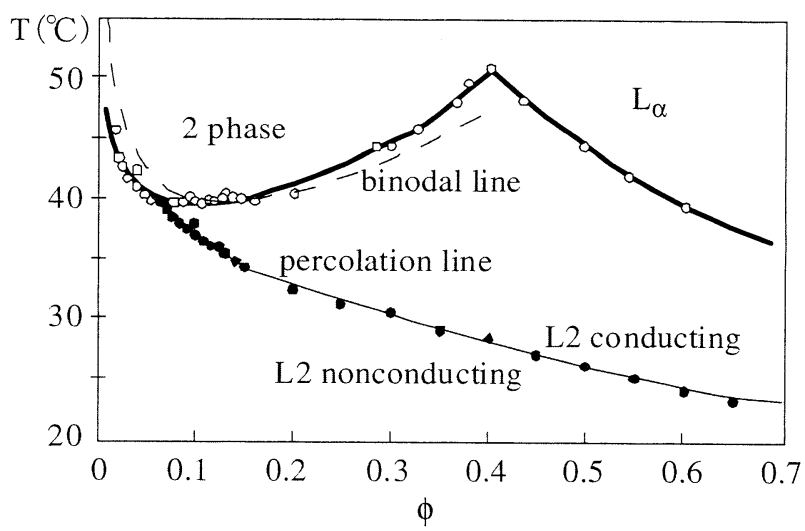

Fig. 3 水と AOT のモル比を 40.8 にした場合の droplet 濃度 と温度に対する相図。(C. Cametti, P. Codastefano, P. Tartaglia, S.H. Chen \& J. Rouch, Phys. Rev. A, 45, R5358 (1992))。 
4） $\phi>0.4$ の「濃厚 droplet」の場合は, 温度上昇に

よりラメラ構造に転移する。

以上のことがらの他に, 相転移温度より低温側に percolation line が存在すること, $\mathrm{NaCl}$ 等の塩を加えること により温度上昇の効果を抑制することができること， $\phi$ を上昇させるに従ってレオロジー的振舞いに異常が現れ $\phi=0.6$ 付近に“glass-like transition”が起きることな ど，様々な実験事実が知られている。そしてそれらによ り,この系で温度による構造の変化は AOT の親水基 ヘッドからの $\mathrm{Na}^{+}$イオンの解離度が上がることに起因し ていること, droplet 間に短距離の引力相互作用が働い ていること等が明らかになっていた。

\section{4 圧力の効果}

圧力は温度と並ぶ重要な熱力学的パラメータであると 言うことは，ヘルムホルツの自由エネルギーの変化 $d F$ が次の形で書けることからも分かる。

$$
d F=-P d V-S d T
$$

ここで $P$ は圧力, $d V$ は体積変化, $d T$ は温度変化, $S$ は エントロピーである。従って温度変化だけでなく圧力変 化も調べることにより，物質の性質がより明確にでき る。また熱力学の教科書にもあるようにクラウジウス ・ クラペイロンの関係

$$
\frac{d T}{d P}=T \frac{d V}{d H}
$$

が成り立ち右辺は負になるのが普通なので，通常は温度 の効果と圧力の効果が逆になる。

圧力は，応用的な面から見ても非常に重要である。例 えば食品加工における圧力の利用は非常に幅広く行われ ており，ジャムやジュース，餅や拪など圧力加工され た商品が市場にも出回っている ${ }^{10)}$ 。更に深海では千気圧 を超える圧力でも生きている生命体があるし，圧力を上 げると麻酔が効かなくなる効果（麻酔作用の圧拮抗）も 知られている。このような圧力効果の重要性に関わら ず，圧力実験は温度に比べて格段に難しいため，ソフト マター系に関する研究例は多くないのが現状である。

その状況は AOT 系についても同様である。数少ない 実験結果は相図の振舞いや臨界現象, 電気抵抗測定等の 圧力依存性は温度上昇と同様である事を示していること から ${ }^{11-13)}$ ，この系の構造の圧力変化は温度変化と同じで ある，と信じられていたように思われる。しかしなが ら，上述したように熱力学的には温度と圧力は系の構造 と物性に関して逆の働きをするのが普通であり, 温度変 化と圧力変化が同じである要因は自明ではない。また $\mathrm{AOT}$, 水, 油の 3 元系の場合には油の種類によって違 うのも特徴的である。温度上昇と圧力上昇が同じ働きを
する，すなわち温度・圧力相図で相境界の傾き $d T / d P$ が正になるのは油としてデカンやオクタンなど疎水基 チェーンが比較的長い場合であり，ブタンなど短い油を 用いた場合は $d T / d P$ が負になったり，あるいはもっと 複雑な相図になることも分かっている ${ }^{13)}$ 。従ってこれら の結果から圧力効果は, 温度変化のように親水基へッド からのイオン解離が原因ではなく疎水基側の変化が関係 していることが示唆されるが，しかしその詳細について は全く分かっていなかった。そこで我々は中性子小角散 乱, X 線小角散乱, 中性子スピンエコー法を用いてこの 系の構造とダイナミクスの温度変化と圧力変化を調べ, それらを比較してミクロな要因を明らかにした。

\section{5 中性子小角散乱}

中性子小角散乱と X 線小角散乱はどちらも回折現象 を用いて物質の構造を調べる方法だが, 通常の結晶解析 で行われる散乱角 $\left(2 \theta=10^{\circ} \sim 130^{\circ}\right.$ 程度) に比べて非常 に小さな角度（通常は $1^{\circ}$ 以内）で測定する点に特徴があ る。波長 $\lambda$, 散乱角 $\theta$, 繰り返し周期 $d$ の間には次の Bragg $の$ 関係式

$2 d \sin \theta=n \lambda$ が成り立っているので， $\theta$ が小さいということは $d$ が大 きいということである。X 線や中性子の波長は通常 1〜

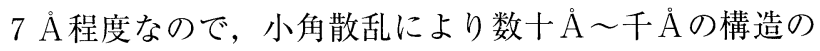
特徴を明らかにすることができる。

中性子と X 線はどちらも放射線の一種だが，物質の 構造を調べるという立場から言えば大きな違いがある。 それはX 線が主に原子核の周辺の電子雲によって散乱 されるのに対して, 中性子は原子核との相互作用により 散乱されるという違いによる。X 線の散乱の強さはほぼ 原子番号に比例するが，中性子の場合はそうではない。 原子核が違えば散乱能が大きく変わり, 原子番号に比例 しない。すなわち X 線では見ることが難しい軽元素で も観察することができる。また同位元素の違いを認識で きることも特徴的である。従って，例えば水素を重水素 に入れ替えることにより化学的性質をほとんど変えるこ となく中性子の散乱条件を変化させることができ，これ によって精密な構造解析が可能となるのである。

その一つの例として, AOT 系で droplet 濃度 $\phi$ を変 化させながら測定した例を紹介しよう ${ }^{14)}$ 。上述のように AOT 系の場合 droplet のサイズは水と AOT の体積分率 で決まる事が知られていたが，これを実証することは実 はそれほど簡単なことではない。それは，構造を空間に 関してフーリエ変換したものである小角散乱のデー夕 は，位相情報を含まないためダイレクトに実空間に変換 できず，必ずモデルを立てて解析する必要があるからで 
ある。特に難しいのがある程度以上の濃度の系（通常は 散乱体の濃度が $1 \%$ 以）の場合で，散乱体 1 個のフー リ工変換である形状因子 $P(Q)$ だけでなく，散乱体同士 の相関からくる構造因子 $S(Q)$ も考虑する必要がある。 散乱関数は通常（単分散の場合）これら 2 つの因子の積 として表す事ができる。

$$
\frac{d \Sigma}{d \Omega}(Q)=P(Q) S(Q)
$$

すなわち，小角散乱のデー夕を解析するためには，形状 因子と構造因子それぞれについてモデルを立てて解析す る必要があるのである。ここで形状因子についてのモデ ル化はそれほど困難ではないのだが，構造因子について のモデル化は一般に難しい。そこで我々は「相対形状因 子」と言う概念を導入することにより構造因子について の議論を避けて droplet 形状だけを議論できるようにし， それにより $\phi<0.7$ の範囲で擬一元系描像が成り立って いることを示した。

マイクロエマルション系の場合，水と油に軽水素化物 を用いるか重水素化物を用いるかにより中性子散乱コン トラストを様々に変化させる事ができる。Fig. 4 の（a） と（b）はその例で, 水に重水, 油に軽水素化物を用い

(a)

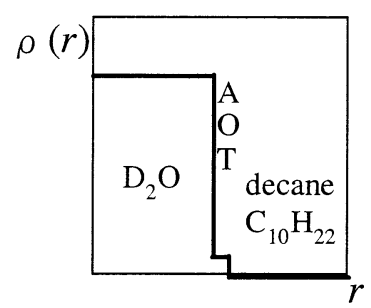

(b)

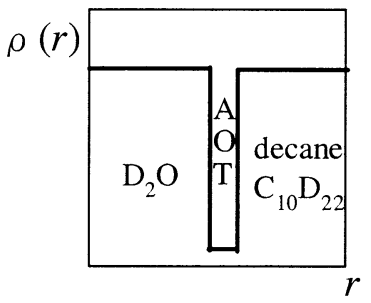

(c)

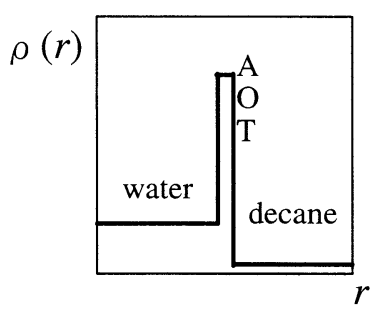

Fig. 4 散乱振幅密度の droplet 中心から の距離 $r$ による分布。(a) と (b) は中性子に対するもので, (a) は bulk contrast,（b) は film contrastに対応する。また (c) はX線に対するものである。 た（a）は droplet の水滴の部分と周辺とのコントラスト が見えるため, “bulk contrast” と呼ぶ。一方水, 油の どちらも重水素化物を用いた（b）は水, 油の部分と界 面活性剤膜との差が見えるため “film contrast”と呼ば れる。

この bulk contrastの試料と film contrastの試料を中 性子小角散乱で見た場合を考える。すると形状因子 $P(Q)$ は当然それぞれのコントラストに応じたもの（それぞれ $P_{\text {bulk }}(Q), P_{\text {film }}(Q)$ とする) になるが, コントラストの違 いによって物理的性質が同じなら構造因子 $S(Q)$ は同じ はずである。従ってそれぞれの小角散乱プロファイル $I_{\text {bulk }}(Q), I_{\text {film }}(Q)$ の比を取ると, 構造因子に依存しない 次の表式になるであろう。

$$
R(Q)=\frac{I_{\text {bulk }}(Q)}{I_{\text {film }}(Q)}=\frac{P_{\text {bulk }}(Q)}{P_{\text {film }}(Q)}
$$

我々はこの $R(Q)$ を相対形状因子と名付けた。

実験は日本原子力研究所の研究用原子炉 JRR-3M に 東京大学物性研究所が設置している中性子小角散乱装置 SANS-Uを用いて行った。AOTと水の混合比はモル分 率が $1: 38.2$ になるようにし，これらのデカンに対する 体積分率 $\phi$ が $0.05 \sim 0.75$ の範囲内になるように bulk contrast, film contrast それぞれについて調整し, 各試料 からの小角散乱を測定した。

Fig. 5 は bulk contrast, film contrast それぞれについ ての散乱プロファイルと, これらの割り算から得た相対 形状因子 $R(Q)$ のプロファイルである。また Fig. 6 にこ の相対形状因子のプロファイルの droplet 濃度依存性を 示す。これから明らかなように, $\phi<0.7$ でそれらはほ

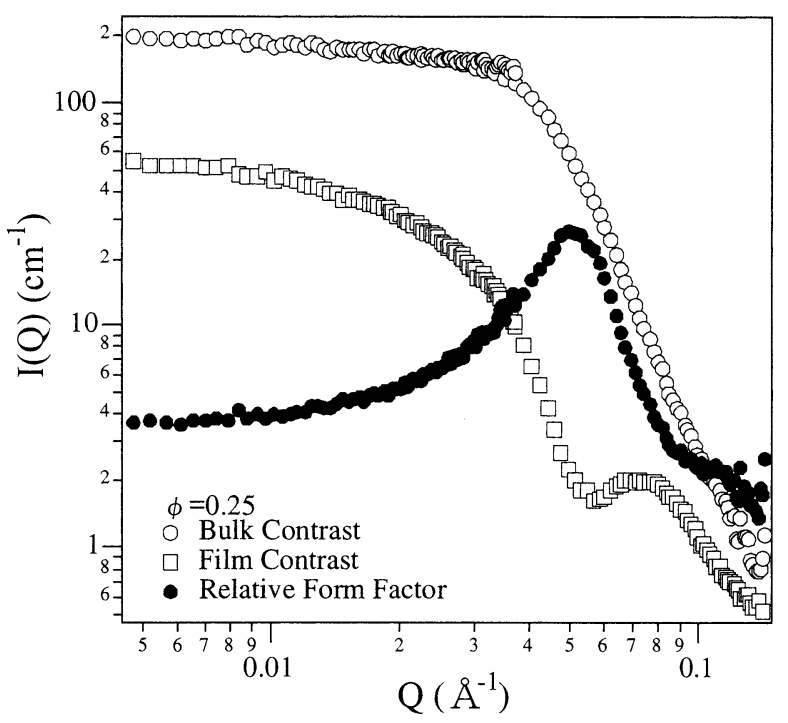

Fig. $5 \phi=0.25$ の試料の bulk contrast $(\bigcirc)$, film contrast （口）からの中性子小角散乱データと，これらから得 られた相対形状因子 


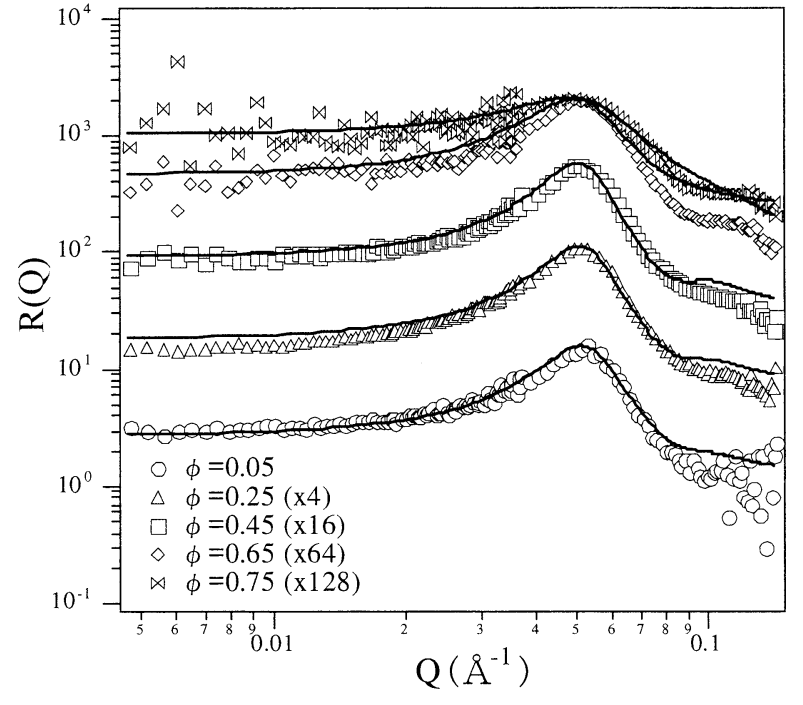

Fig. 6 相対形状因子の droplet 濃度依存症。

ぼ一致するプロファイルとなった。すなわち相対形状因 子の比較と言う実験結果だけから，水滴の形状は水滴濃 度によらない，すなわち「擬一元系流体系」の描像が正 しい事を示す事ができた。

次に，中性子小角散乱を用いて濃厚 droplet $(\phi=0.6)$ 構造が温度上昇，圧力上昇によりどのように变化するか を調べた ${ }^{15.16)}$ 。Fig. 7 は温度上昇による中性子小角散乱 プロファイルの変化で，中性子ビームを当てる位置を変 えて試料上部と下部を別々に測定している。ここでは温 度変化のみを示しているが，圧力変化もほぼ同様であ る。室温常圧においては均一な droplet 構造なので，試 料の位置によらずに幅の広い単一ピークのプロファイル となる。そしてこのピークは温度上昇，圧力上昇によっ て強度を減じながら高角側にシフトする。試料下部にお いては，ある温度・圧力から $Q=0.09 \AA^{-1}$ 付近にラメラ 構造に由来する新たな鋭いピークが現れる。一方試料上 部はややピークがブロードになりピーク位置がシフトす るが大きな変化はない。この状況を特徴づけるために， プロファイルを次のモデルにより説明を試みた。

$$
I(Q)=\frac{A}{C_{0}+C_{2} Q^{2}+C_{4} Q^{4}}
$$

Teubner and Streyにより導かれたこの関数形は，次 の相関関数

$$
g(r)=\frac{d}{2 \pi r} \exp \left(-\frac{r}{\xi}\right) \sin \left(\frac{2 \pi r}{d}\right)
$$

のフーリエ変換になっている ${ }^{17)}$ 。すなわち水と油の領域 が交互に並んでいてその相関が距離とともに減少してい くような構造を表している。droplet や bicontinuous 等 の構造にはよらない現象論的な散乱関数であるため詳細
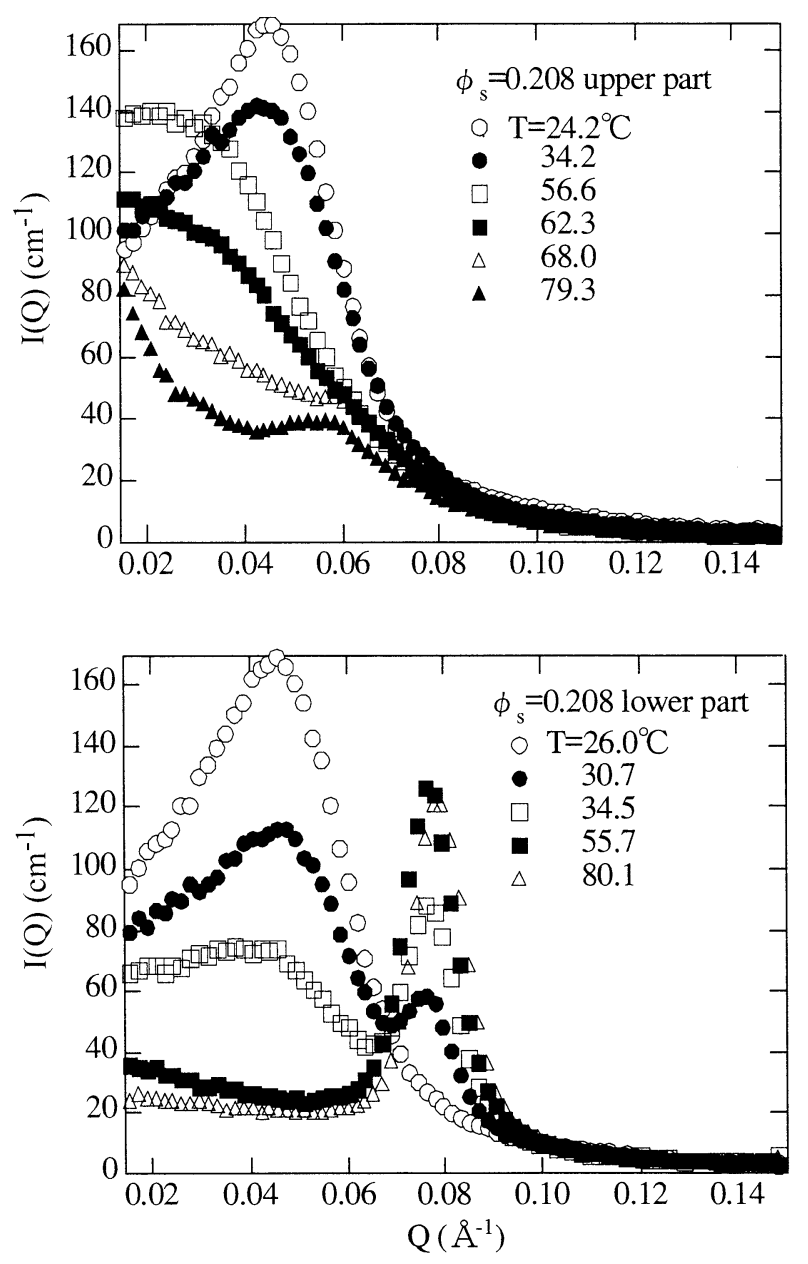

Fig. 7 濃厚 droplet 相の中性子小角散乱プロファイルの温度 依存性。上は試料の上部に, 下は試料の下部にビー 厶を当てて得られたもので，高温相が 2 相に分離し ていることが分かる。

な評価はできないが，おおまかな傾向を調べるのに適し ている。

(7)式でフィッティングして得られる結果から，系の 特徴的な長さ $d$ と相関距離 $\xi$ を次のように求める事がで きる。

$$
\begin{aligned}
& d=2 \pi\left[\frac{1}{2}\left(\sqrt{\frac{C_{0}}{C_{4}}}-\frac{C_{2}}{2 C_{4}}\right)\right]^{-1 / 2} \\
& \xi=\left[\frac{1}{2}\left(\sqrt{\frac{C_{0}}{C_{4}}}+\frac{C_{2}}{2 C_{4}}\right)\right]^{-1 / 2}
\end{aligned}
$$

実験から得られた $d$ の温度変化，圧力変化を Fig. 8 に 示す。 $d$ は温度上昇と圧力上昇によりいったん小さくな るが，ラメラのピークの出現とともに増大に転じ， ラメ ラのピークの成長が止まる温度・圧力で $d$ の増大も終わ る。従って $d$ が最小となる（ラメラのピークが出現す る）温度と圧力を転移開始温度 $\left(T_{\mathrm{s}}\right) \cdot$ 圧力 $\left(P_{\mathrm{s}}\right), d$ の増 


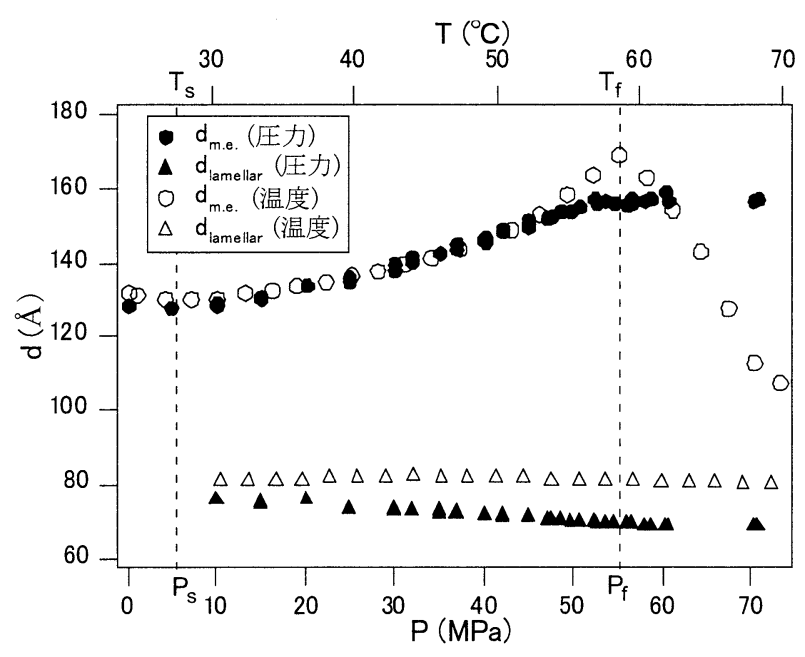

Fig. 8 特徵的長さ $d$ の温度変化 (○は droplet 相, $\triangle$ はラメ ラ相）と圧力変化（はdroplet 相，、はラメラ相）。 上の横軸は温度，下の横軸は圧力で，縦の点線は転 移開始温度・圧力と転移終了温度・圧力を表してい る。

大が止まる温度と圧力を転移終了温度 $\left(T_{\mathrm{f}}\right)$ ・圧力 $\left(P_{\mathrm{f}}\right)$ と 呼ぶ。この結果から，少なくとも $d$ の変化に関しては温 度変化と圧力変化にはほとんど違いがないことが分か る。また Fig. 8 にと $\xi$ の比で与えられるパラメータ $D$ (系の乱れ具合を表す指標で, disorder parameter と呼 ぶ）の温度変化，圧力変化を示す。これによると $D$ は $T_{\mathrm{s}}$ と $P_{\mathrm{s}}$ において 0.446 を越えることが分かるが，この 值は経験的に droplet 構造と bicontinuous 構造を分ける 值であることが知られている。以上の結果より，温度上 昇，圧力上昇によりいずれも droplet 構造は 2 相に転移 し, 試料上部は bicontinuous 構造に, 試料下部はラメラ

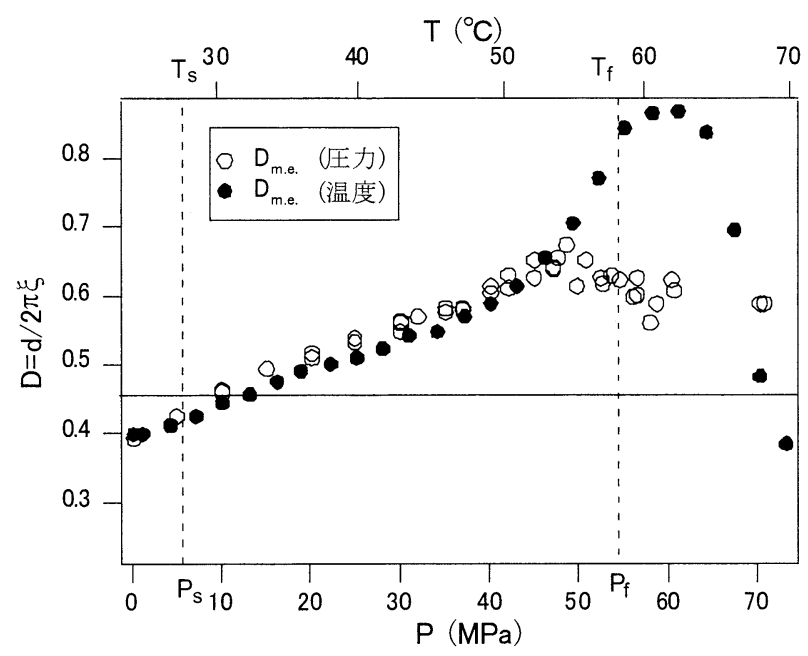

Fig. 9 disorder parameter の温度変化 $\bigcirc$ と圧力変化○上の 横軸は温度，下の横軸は圧力で，縦の点線は転移開 始温度・圧力と転移終了温度・圧力を表している。
構造になることが確認できた。

\section{$6 \mathrm{X}$ 線小角散乱}

前述したようにX 線は電子雲の分布を見る手法であ ると言う点で中性子と違う情報が得られるが，それ以外 にも重要な特徵がある。それは中性子に比べて線源の強 度が非常に強いこと（特にシンクロトロン放射光を用い た場合)，そして波長分解能や角度分解能が高い「良質」 なデー夕が得られることである。従って中性子を用いた 場合に比べて, 散乱プロファイルの詳細な解析に向いて いる。我々はこの特徴を用いて X 線小角散乱プロファ イルの温度変化と圧力変化を比較して, AOT 系の構造 の温度変化と圧力変化のミクロスコピックな要因の違い について議論することができた ${ }^{18)}$ 。

実験は高エネルギー加速器研究機構・物質構造科学研 究所 Photon Factory のビームライン BL-40 B 2 の X 線 小角散乱装置を用いて行った。試料はAOT と水のモル 分率が 1:40.8で， $\phi$ が 0.6 のものを用いている。試料調 整はデカンに軽水素化物のみを用いている以外, 中性子 小角散乱の場合と同様である。

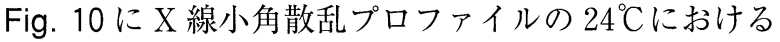

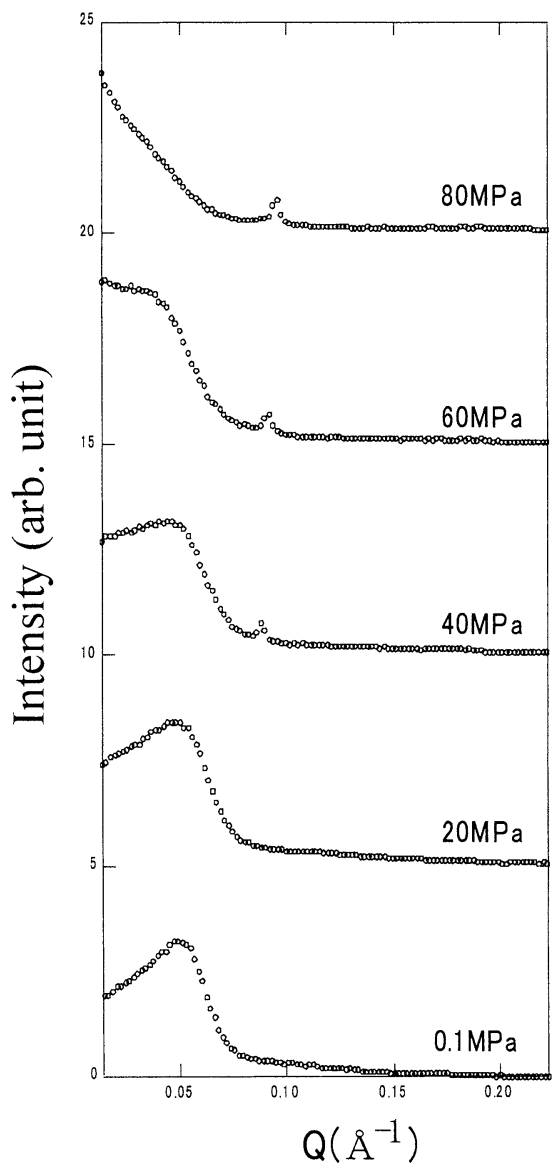

Fig. 10 X 線小角散乱プロファイルの圧力変化の例。 


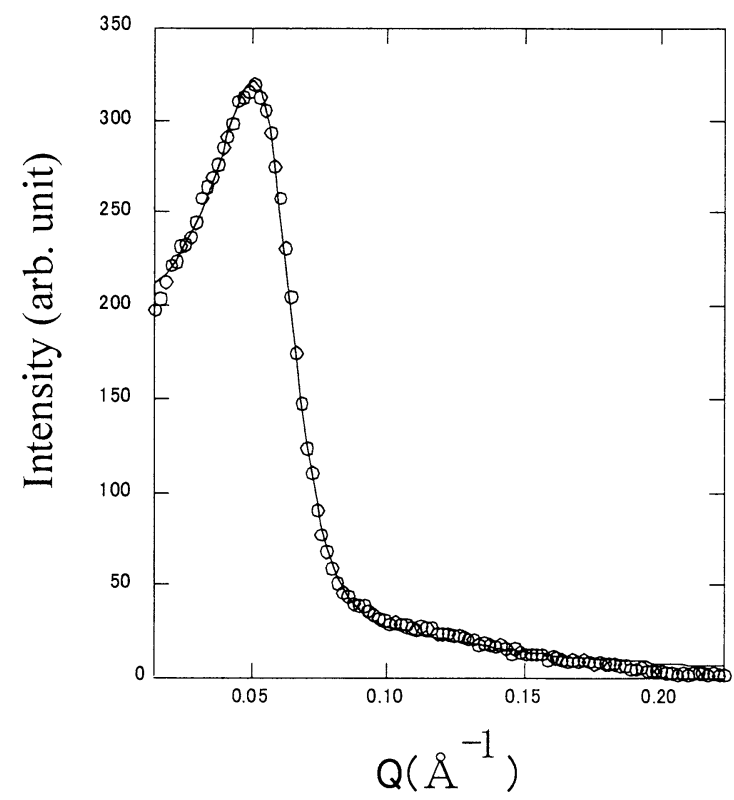

Fig. 11 濃厚 droplet 構造の X 線小角散乱プロファイル をモデルによりフィッティングした例。

圧力依存性を示す。室温常圧において $Q=0.05 \AA^{-1}$ 付近 に幅の広いピークが見られるが，これは droplet 間の相 関に由来するものである。また圧力が $30 \mathrm{MPa}$ 以上で は，中性子小角散乱で見られたようにラメラ構造の繰り 返し周期に対応する高角側のピークが見える。ただしX 線小角散乱用の高圧セルは試料下部のみを見ているた め，ラメラ構造からの散乱のみが見えている。我々はこ のプロファイルの，特に転移点以下における変化の様子 をモデルを用いて解析し，フィットパラメータの温度依 存性と圧力依存性を比較してその違いを浮き彫りにする ことにした。

Fig. 11 に, droplet 構造からの X 線小角散乱プロファ イルの例を示す。X 線に対する散乱振幅密度分布は Fig. 4(c)のようになっているので，本来は水とデカンの散乱 振幅密度差だけでなくAOT 膜とデカンの散乱振幅密度 差からの散乱も考える必要があるが，水とデカンからの 散乱の方が相対的に大きいので次の式で近似できる。

$$
I(Q)=L(Q)+P(Q) S(Q)
$$

ここで $P(Q), S(Q)$ は droplet の形状因子とその相関か ら来る構造因子であり， $L(Q)$ は $\mathrm{AOT}$ 分子の濃度摇ら ぎに由来するものである。形状因子については中性子小 角散乱の結果より球状 droplet からの散乱の式を用い $3^{19)}$ 。

構造因子に関しては，他の実験結果から水滴間に短距 離の引力ポテンシャルが存在する事が分かっているの で，半径 $R_{0}$ の硬い核とその外側のわずかの範囲に及ぶ 深さ $\Omega$ の井戸型ポテンシャルを含む系に対する構造因
子の表式を採用する20)。その式はやや複雑だが解析的な 形をしているので，そのまま実験データへのフィッティ ングが可能である。Fig. 11 のデー夕点に重なる曲線はそ のフィッティングの結果で，データと良く一致している と同時に得られたフィットパラメータも reasonable な 值であり，フィッティングとモデルが正しい，と考えて 良い。

この解析から得られた，(a) droplet 間距離 $2 R （ R$ は droplet 間ポテンシャルの到達距離を表すが，この組成 ではdropletはほぼ最密充填されているので $2 R$ を droplet の中心間距離と解釈して良い) と（b） droplet の hard core の半径 $R_{0}$ の圧力依存性を Fig. 12 に示す。 これは, いくつかの温度に対して得られたデー夕を転移 開始圧力 $P_{\mathrm{s}}$ を基準にした圧力の関数として表している。 (a) の振舞いは中性子小角散乱で得られた特徴的長さ $d$ の圧力依存性（Fig. 8）と consistentであり，このこと から $d$ が droplet 間距離に対応することが分かる。また

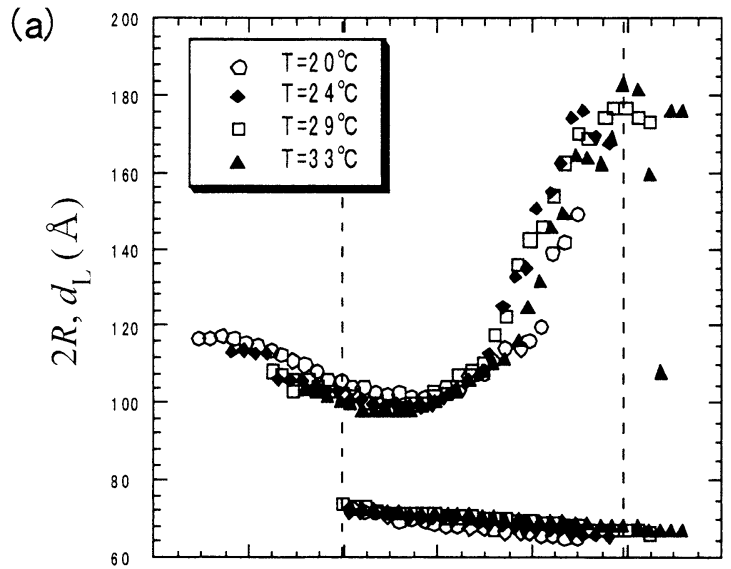

(b)

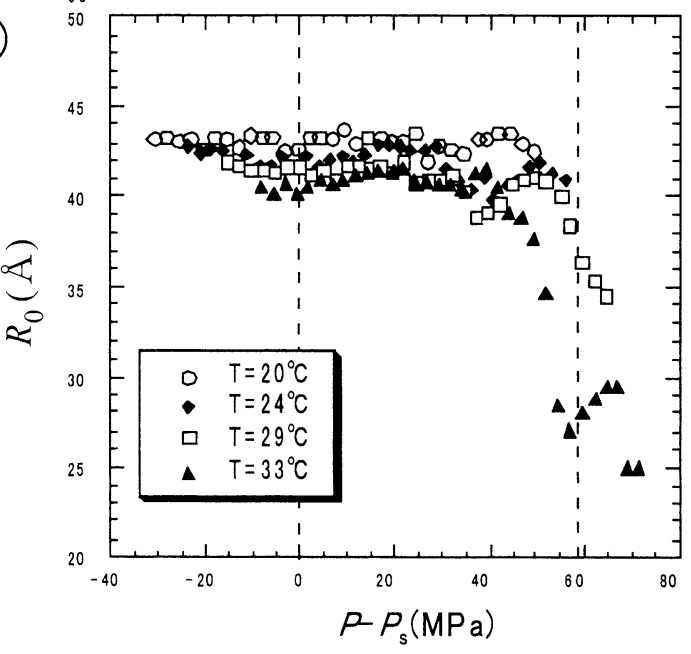

Fig. 12 X 線小角散乱により得られた, droplet 間距離 $2 R$, ラメラの面間隔 $d_{\mathrm{L}}$, droplet の水の部分の 半径 $R_{0}$ の温度, 圧力依存性。横軸は転移開始圧 力により規格化した圧力を表している。 


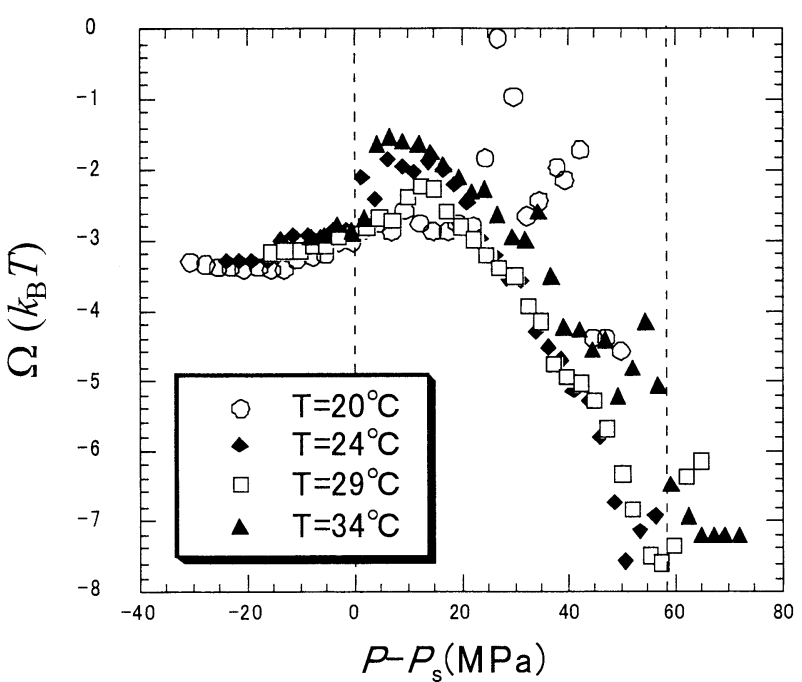

Fig. $13 \mathrm{X}$ 線小角散乱により得られた, droplet 間の引力ポテ ンシャル $\Omega$ の温度, 圧力依存性。横軸は転移開始圧 力により規格化した圧力を表している。

同じ系に対して中性子小角散乱実験と X 線小角散乱実 験を行い違うモデルで解析したが，この事実がこれらの モデルの間の関係とそれぞれの解析の妥当性を示してい る。

Fig. 13 には, droplet 間の近距離引力ポテンシャルの 深さ $\Omega$ の圧力依存性を, Fig. 12 と同様に $P_{\mathrm{s}}$ を基準にし た圧力の関数として表した。データのばらつきは大きい ものの圧力を上げれば $\Omega$ が小さくなる，すなわち引力 が強くなる傾向が出ていることは明らかなのに対し, 温 度による違いは現れない。すなわちこの実験結果から， droplet 間の引力は温度には依存しない一方で，圧力に より増大することが分かった。すなわち, Fig. 14 に示す ように疎水基間の引力の増大が, droplet からラメラへ の構造変化の原因であると解釈できる。第 5 節に記した ように, AOT 系の温度変化のミクロな要因は親水基 ヘッドからのイオン解離であると考えられていたが，圧 力では踈水基側が変化していることが示唆されていた。 今回の実験結果はその予想に対する実験的な証拠を提示 したことになり，構造形成要因を明らかにする上で重要 な結果が得られたと言って良いのではないだろうか。

別の面から見て重要なことは，ミクロな要因が違って いるのにも関わらず，セミミクロなスケールではほぼ同 様の相転移が起こっていることである。これはセミミク ロスケールの構造形成と相転移を記述するにはある程度 粗視化したモデルを用いてミクロな変化を繰り达んでし まって良い事を意味する。すなわち，式(1)で特徽づけ られるような現象論的モデルで系の振舞いが記述できる ことを正当化していると言って良いように思われる。

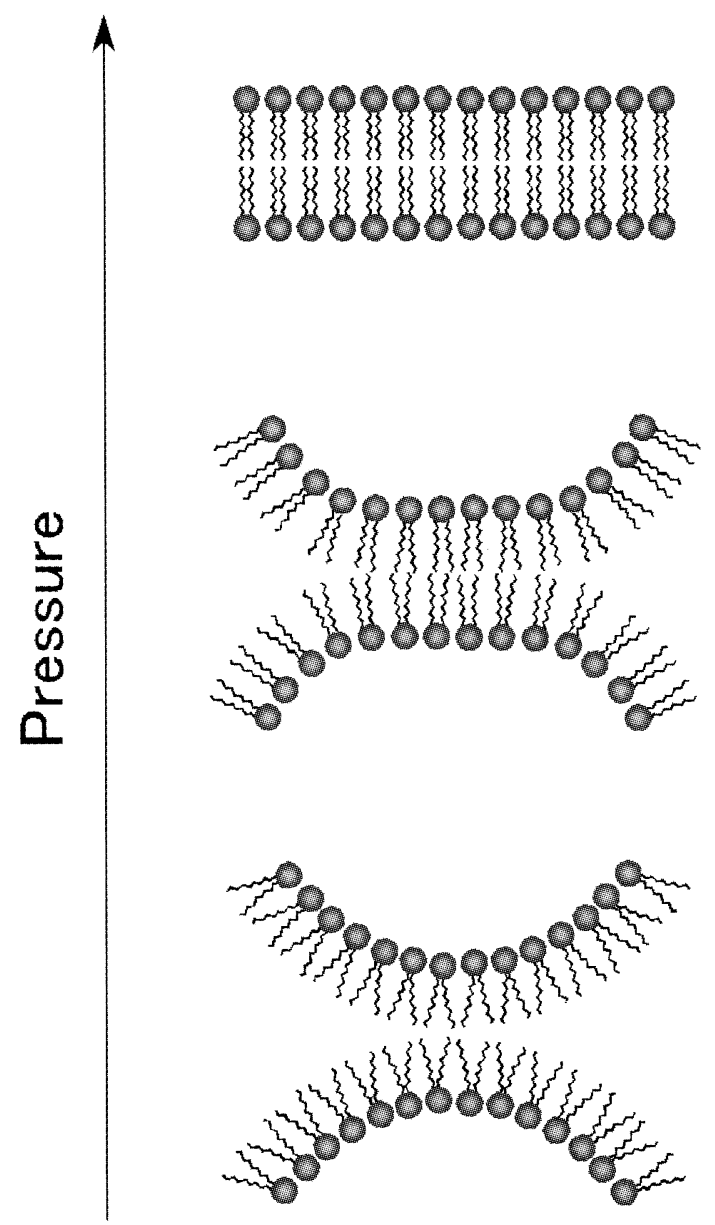

Fig. 14 圧力により droplet からラメラ構造になるメ カニズムの模式図。圧力上昇により AOTの 疎水基間の引力が増大し，それによってフ ラットな膜が形成される。

\section{7 中性子スピンエコー}

第 2 節で述べたように，マイクロエマルション系の構 造形成を記述するためには, 界面活性剤膜の曲げ剛性率 $\kappa$ と, saddle-splay 剛性率 $\bar{\kappa}$, 及び自発曲率 $R_{\mathrm{s}}^{-1}$ を実験 的に定めることが重要である。その方法としてはマクロ スコピックな方法や中性子小角散乱による方法などいく つか試みられているが, 最も直接的で信頼性が高いのは 中性子スピンエコーを用いる方法である。

中性子非弾性散乱の方法の一つである中性子スピンエ コー法は，1970 年頃にハンガリーの Mezeiにより考案 された ${ }^{21)}$ 。通常の中性子非弾性散乱は, 中性子飛行時間 分析や結晶による分光によって試料で散乱される前後の 中性子のエネルギー変化を調べるが，一般にこれらの方 法は波長分解能とエネルギー分解能が直接結びついてい る。そのためエネルギー分解能を上げようとすると波長 分解能も上げなければならなくなり, 中性子強度を落と 
さずエネルギー分解能を上げるには限界がある。それに 対して中性子スピンエコー法は, 中性子スピンの磁場中 での Larmor 歳差運動を時間の「ものさし」として利用 することにより，波長分解能を変えることなくエネル ギー分解能を良くする事ができる。測定可能なエネル ギー分解能は通常の中性子非弾性散乱で典型的な $\mu \mathrm{eV}$ 程度より 2 3 桁小さく, neV 程度まで測定できる。す なわちマイクロエマルションのような比較的大きな構造 のゆっくりした運動を調べるのに向いている。その他測 定デー夕として, 運動量 $Q$ と時間 $t$ の関数である中間相 関関数 $I(Q, t)$ が与えられるため, 緩和現象を理解する のに適しているという特徴がある。更に第 5 節で述べた ように，水と油を重水素化することによって界面活性剂 からの散乱のみに注目することができる。以上の事から 中性子スピンエコーは，マイクロエマルションの界面活 性郕膜の動的振舞いを調べるには最適な方法だと言える のである。

実験は，東京大学物性研究所が JRR-3 M に設置する 中性子スピンエコー装置 ISSP-NSE を用いて行った ${ }^{22)}$ 。 我々は希薄 droplet 相と濃厚 droplet 相の試料双方を用 意してそれぞれの温度変化，圧力変化を測定し，consistent な結果を得ているが，スペースの関係もあるのでこ こでは希薄 droplet 相で得られた結果のみを紹介す $る^{23,24)}$ 。濃厚系の結果について興味のある方は, 別の解 説記事を参照して頂きたい ${ }^{25)}$ 。

試料は AOT と水のモル分率を 18.4 とし, 水, デカン それぞれについて重水素化物を用いて AOT の膜のみが 見えるようなコントラスト（film contrast）とした。 droplet の体積分率は打よそ0.1とし, 中性子小角散乱測 定により droplet 半径 $R_{0}$ とその多分散度 $p$, 及び常圧 $(P=0.1 \mathrm{MPa})$ に打ける相分離温度 $T=59^{\circ} \mathrm{C}$ と室温（ $T=$ $25^{\circ} \mathrm{C}$ ）における相分離圧力 $P=43 \mathrm{MPa}$ を決めた。

実験は，圧力を常圧に固定して温度を $T=10^{\circ} \mathrm{C}$ から $65^{\circ} \mathrm{C}$ まで変化させた “Temperature Run”と温度を室温 に固定して圧力を $0.1 \mathrm{MPa}$ から $60 \mathrm{MPa}$ まで変化させた “Pressure Run”と 2 系統行って，結果を比較した。

中性子スピンエコーで得られる典型的なデー夕の例 を, Fig. 15 に示す。横軸はエネルギー遷移のフーリエ変 換で，時間と同じ次元を持つ。縦軸は中間相関関数 $I(Q$, $t$ ）で，時刻ゼロにおける空間相関 $I(Q, 0)$ (すなわち中性 子小角散乱により得られるデータと同じもの）が時間と ともに減少する様子を表していると考えられる。すなわ ち中間相関関数とは，ある波数 $Q$ に対応する長さの空 間相関の，時間相関関数を見ていると解釈できる。

このプロファイルを理解するには， Milner and Safran が提案し，AOT 系について Huang らが適用したモデル

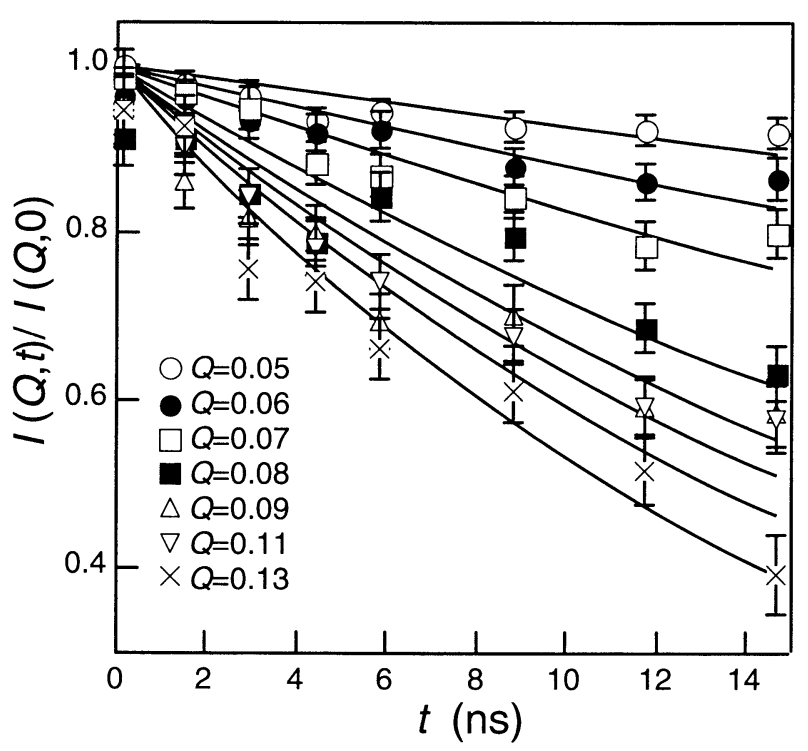

Fig. 15 中性子スピンエコーで得られる中間相関関数の例。

を用いる ${ }^{25,26)}$ 。これは droplet の変形を球面調和関数で 展開し，それぞれの変形モードが特有の時定数を持つと 言うモデルである。これによると中間相関関数は次のよ うに書く事ができる。

$$
\begin{aligned}
I(Q, t)= & \left\langle\operatorname { e x p } ( - \Gamma _ { 0 } t ) V _ { \mathrm { s } } ^ { 2 } ( \Delta \rho ) ^ { 2 } \left[ f_{0}(Q R)\right.\right. \\
& \left.\left.+\sum_{l \geq 2} \frac{2 l+1}{4 \pi} f_{l}(Q R)\left\langle\left|u_{l}\right|^{2}\right\rangle \exp \left(-\Gamma_{l} t\right)\right]\right\rangle
\end{aligned}
$$

ここで $V_{\mathrm{s}}$ はdroplet の体積， $\Delta \rho$ は界面活性剂膜の中性 子散乱密度, $f_{l}$ は $l$ 次のモードの変形に関する形状因子 で， $\Gamma_{l}$ はその変形の緩和時間の逆数である。ここで，特 に最低次の変形モードである $l=2$ は球がピーナッッ状 に変形する事を示す。これより大きい次数のモードは当 然より複雑な変形を表すが，対応する空間スケールも小 さくなるためここで測定している $Q$ レンジでは見えな いはずである。従って今の解析では高次の変形モードを 考慮する必要はなく,$l=2$ だけを考えれば良い。よって 中間相関関数は簡単に次の形で近似できる。

$$
I(Q, t)=I(Q, 0) \exp \left(-\left(D_{\text {tr }}+D_{\text {def }}(Q)\right) Q^{2} t\right)
$$

ここで $D_{\mathrm{tr}}$ は droplet の並進拡散に， $D_{\mathrm{def}}$ は変形拡散に 関する拡散係数である。 $D_{\text {def }}$ は $Q$ の関数として次の形に 書ける。

$$
D_{\text {def }}(Q)=\frac{5 \Gamma_{2} f_{2}\left(Q R_{0}\right)\left\langle\left|u_{2}\right|^{2}\right\rangle}{Q^{2}\left[4 \pi\left[j_{0}\left(Q R_{0}\right)\right]^{2}+5 f_{2}\left(Q R_{0}\right)\left\langle\left|u_{2}\right|^{2}\right\rangle\right]}
$$

実験で得られる中間相関関数を式(13)でフィッティン グして $D_{\mathrm{tr}}$ と $D_{\mathrm{def}}(Q)$ を求め, 得られた $D_{\mathrm{def}}$ を式(14) で 
フィットして $l=2$ の変形に対応する decay rate $\Gamma_{2}$ を求 める。この $\Gamma_{2}$ と中性子小角散乱から得られた droplet 半 径 $R_{0}$, 及び droplet の内部と外部の粘性係数を用いるこ とにより, 界面活性剤膜の曲げ剛性率 $\kappa$ を求める事がで きる。

Fig. 16 に，得られた曲げ剛性率 $\kappa$ の温度依存性と圧 力依存性を示す。横軸は室温常圧と相分離点で規格化し てある。このグラフより，温度上昇により のに対して，圧力を上げることにより増加することは明 らかである。すなわち，温度を上げると界面活性剤膜は 柔らかくなるのに対して, 圧力上昇により堅くなること が分かった。

これがどのような要因によるのかを, 前述した界面活 性剂膜の構造の温度 - 圧力依存性と関連付けて考えてみ よう。Fig. 17 に模式的に示したように，温度上昇により 影響を受けるのは界面活性剤の親水基へッドの部分であ る。ここからカウンターイオン $\left(\mathrm{Na}^{+}\right)$が解離して親水 基へッド間に静電的な斥力が生じ, 親水基ヘッドの占め る面積が増大する。これにより自発曲率が変化するが, それだけでなく界面活性剤分子の自由体積が増大して， 分子運動に関するエントロピーも増大するであろう。そ の効果は，「エントロピー力」として膜の剛性率，すな わち「曲げようとする力」に対する応答に影響する。実 際に我々はこの効果を考慮したミクロスコピックなモデ ル ${ }^{28)}$ を適用して，Кの温度変化を説明することができ た。(Fig. 16 の実線)

では，圧力の影響はどのように効いてくるか。前述の

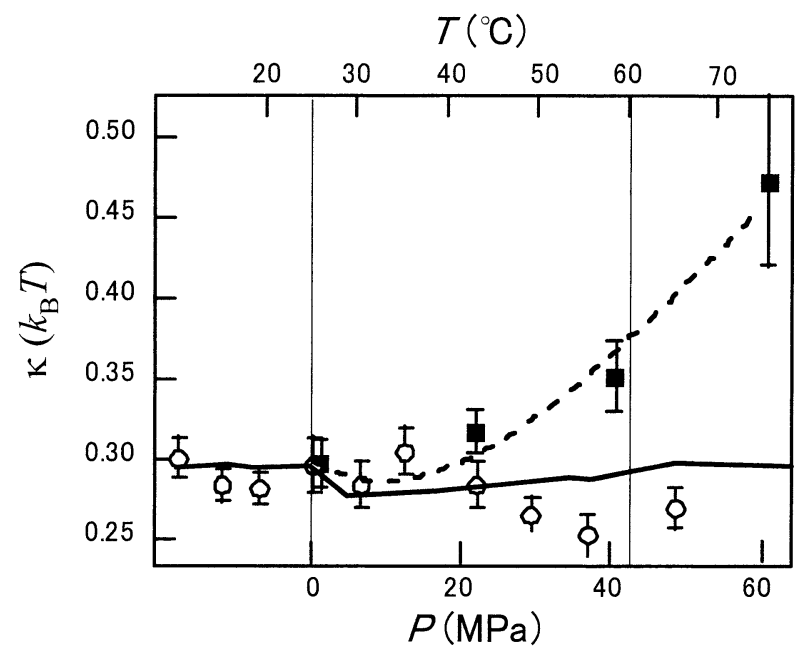

Fig. 16 曲率剛性率 $\kappa$ の温度 $(\bigcirc)$, 圧力 $(\boldsymbol{\square})$ 依存性。図 中の縦線は室温常圧と相分離点を表し，この両者で 温度と圧力を規格化して比較している。実線はミク ロスコピックなモデルにより説明した $\kappa$ の温度変化 で，破線は同じモデルを用いて圧力依存性を計算し たものである。

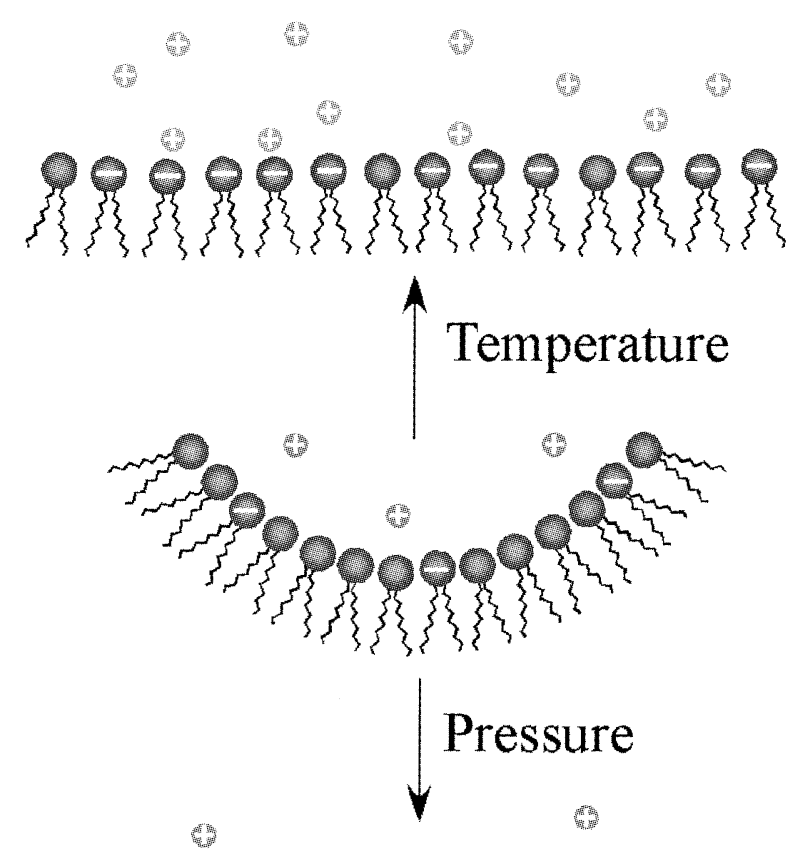

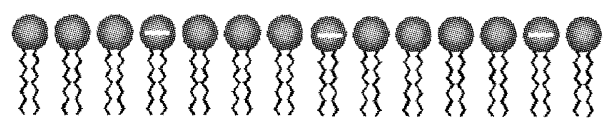

Fig. 17 温度変化と圧力変化による膜の構造変化の模式図。 温度上昇によりイオン解離が進行して自発曲率が小 さくなるのに対して，圧力では疎水基側が変化して 自発曲率が減少する。

ミクロなモデルでは圧力上昇により droplet 間の引力が 増えるとしていたが，これは AOT の疎水基間の引力相 互作用が増大すると言い換えることができる。あるい は, $\mathrm{AOT}$ の疎水基とデカン分子が隣り合うよりも， AOT 分子同士が隣り合った方がエネルギー的に安定に なる，と言い換えても良い。AOT の疎水基間の引力が 増大すれば，当然 AOT 膜は曲げにくくなり曲げ剛性率 Кは大きくなる。これを温度変化の場合と同様にミクロ スコピックなモデルにより曲げ剛性率の圧力依存性を説 明しようとしたのが，Fig. 16 の破線である。ここでは界 面活性剂分子間の相互作用に圧力依存性を仮定して フィッティングしているが，圧力とともに引力が増大す ると言う結果が得られた。すなわち中性子スピンエコー によるダイナミクスの測定とそれによる曲げ剛性率 $\kappa$ の 温度変化・圧力変化に伴う振舞いは，X線小角散乱で得 られた構造変化のミクロな描像と一致する事が分かっ た。

\section{8 おわりに}

以上のように我々は, 中性子小角散乱, X 線小角散 乱，中性子スピンエコーを組み合わせることにより， 
AOT と水，デカンを混合したマイクロエマルションの 構造的な特徴を明らかにし, 温度变化, 圧力変化による 構造変化の要因を分子レベルから解き明かすことができ た。特に両親媒性分子の作るセミミクロ構造の圧力によ る変化の要因をミクロスケールから明らかにした事は, 今後様々な応用研究における未解決な問題へのインパク トを与えることが期待できる。

また，この結果はマイクロエマルション系の振舞いに 関する現象論的な理解にも貢献できたと思われる。第 2 節で述べたように，Helfrichのモデルによれば系の振舞 いは界面活性剂膜の曲げ剛性率 $\kappa$ と, saddle-splay 剛性 率 $\bar{\kappa}$ ，及び自発曲率 $R_{\mathrm{s}}^{-1}$ により記述できると言われてい る。しかし界面活性剤膜は流体膜なので，ずり変形に対 する応答に対応する saddle-splay 剛性率 $\bar{\kappa} は$ 無視して よいと考えるのが普通である。だとすれば，Кが温度と 圧力により逆方向に変化するにも関わらず同じ構造変化 が起きるのはなぜなのか。Helfrich のモデルはどこまで 適用可能なのか。この問題を更に深めていくことによ り，今後のセミミクロスケールの物理学の発展に寄与す る事ができるのではないだろうか。

\section{謝辞}

この一連の研究は, 筆者らが広島大学総合科学部在籍 中に行ったものである。その中で多くの共同研究者の協 力を得ているが，特にマイクロエマルション系の研究の 面白さをご教示いただいた好村滋洋名誉教授と，長年中 性子スピンエコー装置の開発研究を行ってきた武田隆義 教授に感謝したい。また (株) 光高圧機器の小泉光男社長 には，様々なタイプの高圧セルの設計，製作をして頂い た。彼の仕事が無ければ，この研究は成り立たなかった であろう。更に名古屋工業大学の岡林博文名誉教授に は，化学の素養のない我々のために界面活性剤の精製や 取扱い方法などについて詳しくご指導いただいた。中性 子散乱実験は東京大学物性研究所の, X 線散乱実験は高 エネルギー加速器研究機構の実験審査委員会の承認の元 に行っている。更に科学研究費補助金, 日産科学振興財 団, 山田科学振興財団の助成も受けている。ここに合わ せて謝意を表したい。

\section{文献}

1） I.W. ハムレー, ソフトマター入門，シュプリンガー . フェアラーク東京 $(2002)$
2) 好村滋洋, 日本物理学会誌, 54, 164 (1999)。

3) S.A. サフラン, コロイドの物理学, 吉岡書店, (2001).

4) W. Helfrich, Z. Naturforsch., 28 c, 693 (1973).

5) S.H. Chen, J. Rouch, F. Sciortino \& P. Tartaglia, J. Phys: Condens. Matter 6, 10855 (1994).

6) C. Cametti, P. Codastefano, P. Tartaglia, S.H. Chen \& J. Rouch, Phys. Rev. A, 45, R 5358 (1992).

7) M. Kotlarchyk, E.Y. Sheu \& M. Capel, Phys. Rev. A, 46, 928 (1992).

8) M. Kotlarchyk, S.H. Chen, J.S. Huang \& M.W. Kim, Phys. Rev. A, 29, 2054 (1984).

9) S.H. Chen, S.L. Chang \& R. Strey, J. Chem. Phys., 93, 1907 (1990).

10) N.S. Isaacs ed., HIGH PRESSURE FOOD SCIENCE, BIOSCIENCE AND CHEMISTRY, The Royal Society of Chemistry, UK (1998).

11) M.W. Kim, J. Bock \& J.S. Huang, Phys. Rev. Lett., 54, 46 (1985).

12) J. Eastoe, B.H. Robinson \& D.C. Steytler, J. Chem. Soc., Faraday Trans. 86, 511 (1990).

13) J. Eastoe, W.K. Young, B.H. Robinson \& D.C. Steytler, J. Chem. Soc., Faraday Trans., 86, 2883 (1990).

14) M. Nagao, H. Seto, M. Shibayama \& N.L. Yamada, J. Appl. Cryst., 36, 602 (2003).

15) M. Nagao \& H. Seto, Phys. Rev. E, 59, 3169 (1999).

16) M. Nagao, H. Seto, T. Takeda, \& Y. Kawabata, J. Chem. Phys., 115, 10036 (2001).

17) M. Teubner \& R. Strey, J. Chem. Phys., 87, 3196 (1987).

18) H. Seto, D. Okuhara, Y. Kawabata, T. Takeda, M. Nagao, J. Suzuki, H. Kamikubo \& Y. Amemiya, J. Chem. Phys., 112, 10608 (2000).

19) Y.C. Liu, S.H. Chen \& J.S. Huang, Phys. Rev. E, 54, 1698 (1996).

20) M. Kotlarchyk \& S.H. Chen, J. Chem. Phys., 79, 2461 (1983).

21) F. Mezei, ed., Lecture Notes in Physics., Vol. 128 Springer Verlag, Berlin (1980).

22) T. Takeda, S. Komura, H. Seto, M. Nagai, H. Kobayashi, E. Yokoi, C.M.E. Zeyen, T. Ebisawa, S. Tasaki, Y. Ito, S. Takahashi \& H. Yoshizawa, Nucl. Inst. Meth. Phys. Res. A, 364, 186 (1995).

23) Y. Kawabata, H. Seto, M. Nagao \& T. Takeda, J. Neutron Res., 10, 131 (2002).

24) Y. Kawabata, M. Nagao, H. Seto, S. Komura, T. Takeda, D. Schwahn, N.L. Yamada \& H. Nobutou, submitted to Phys. Rev. Lett.

25）長尾道弘, 瀬戸秀紀, 高圧力の科学と技術, 11, 234 (2001).

26) S.T. Milner \& S.A. Safran, Phys. Rev. A, 36, 4371 (1987).

27) J.S. Huang, S.T. Milner, B. Farago \& D. Richter, Phys. Rev. Lett., 59, 2600 (1987).

28) A. Wüger, Phys. Rev. Lett., 85, 337 (2000). 